\title{
Effects of carbamate pesticides intermediates on Escherichia coli membrane architecture: An in vitro and in silico approach
}

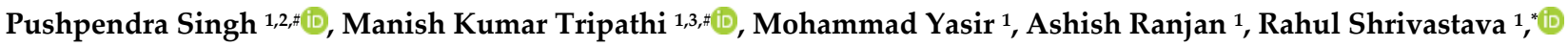 \\ ${ }^{1}$ Department of Biological Science \& Engineering, Maulana Azad National Institute of Technology, Bhopal, Madhya \\ Pradesh 462003 India \\ ${ }^{2}$ State Virus Research and Diagnostic Laboratory, Department of Microbiology, All India Institute of Medical Sciences, \\ Raipur, Chhattisgarh 492099 India \\ ${ }^{3}$ Department of Biophysics, All India Institute of Medical Sciences, New Delhi-110029, India \\ \# These authors have contributed equally to this work. \\ *Correspondence: shrivastavarm1972@gmail.com
}

Received: April 17, 2021 Accepted: August 10, 2021

\begin{abstract}
Methyl isocyanate (MIC), a low molecular weight synthetic aliphatic compound, having an isocyanate group (-NCO), has industrial application. In this study, the effects of methyl isocyanate and its mechanism on outer membrane protein of Escherichia coli were observed using experimental and computational methods. In vitro exposure of $\mathrm{N}$-succinimidyl $\mathrm{N}$-methylcarbamate (NSNM) a synthetic analogue of MIC on E. coli to a final concentration of $2 \mathrm{mM}$ was found to affect the growth curve pattern and changes in cell morphology. Molecular docking studies of MIC and NSNM with E. coli outer membrane protein (OmpW, OmpX, OmpF OmpA), and periplasmic domain (PAL) were performed. The in-silico results revealed that outer membrane protein $\mathrm{OmpF}$ showed the highest negative binding energy, i.e. $\Delta \mathrm{G}-4.11 \mathrm{kcal} / \mathrm{mole}$ and $\Delta \mathrm{G}-3.19 \mathrm{kcal} / \mathrm{mole}$ by NSNM and MIC as compared to other proteins. Our study concludes that methyl isocyanate retains lethal toxicity which leads to cell death due to the membrane protein damage of $E$. coli membrane.
\end{abstract}

Keywords: Methyl isocyanate, Escherichia coli, Toxicity, Membrane architecture, Autodock

\section{Introduction}

Methyl isocyanate is one of the isocyanates derivatives which has many industrial uses. Methyl isocyanates are characterized by the presence of extremely reactive $-\mathrm{N}=\mathrm{C}=\mathrm{O}$ group and have application in the manufacture of adhesives materials, polyurethane foam, coating constituents, plastics, paints, and different kinds of pesticides [1,2]. The generally used isocyanates are methyl isocyanate, diphenylmethane 4, 4'-diisocyanate, hexamethylene diisocyanate, toluene diisocyanate, 1, 5-naphthalene diisocyanate, and isophorone diisocyanate, and all of these are reported for a certain degree of toxicity [3,4]. Methyl isocyanate also exerts severe chronic and acute lethal effects on different organ system [5].

Methyl isocyanate is utilized as an intermediate in the production of carbamate pesticides which were accidentally released from the Union Carbide India Limited (UCIL) plant in the Bhopal gas tragedy, the world's most horrible industrial disaster [6-8]. Thousands of people died with pulmonary oedema, and thousand survived with various diseases like cancer, pulmonary, reproductive, ophthalmic, hematologic, tuberculosis, immunologic and neurological toxicity [9-11]. Numerous theories have suggested for the interaction of MIC with different cell lines MM55.K, B/CCMA.OV, NIH.3T3 and cultured human lymphocytes which justify its toxicological effect [12]. The rigorous mechanism of cell and tissue damage by isocyanate is to induce reactive oxygen species (ROS), which interacts with a different cellular molecule like proteins and nucleic acid, shows the toxic effect, i.e. DNA damage, apoptosis and oxidative stress [12].

Methyl isocyanate binds with glutathione and makes its way into the systemic circulation, affecting the red blood cell membrane, which explains its toxic activity $[13,14]$. Carbamylation effect of methyl isocyanate in brain, liver, kidney, and lung proteins, were also reported $[15,16]$. Cellular proteins interact with methyl isocyanate and alter their membrane permeability, damage membrane structure which leads to the leakage of cell contents, and as a result, cell death occurs [17]. The effect of this methyl isocyanate has been studied to a minimal extent in microorganisms, because of its extreme volatility and toxicity. The mechanisms of toxicity and its impact on natural membrane architecture, particularly microorganism, are still in the necessity of elucidation. Escherichia coli was selected as a model bacterium for exploring the effect of $\mathrm{N}$ succinimidyl N-methylcarbamate (NSNM) a synthetic analogue of MIC, on cell membrane structure and how it creates pores leading to morphology disruption and consequently to cell death. 
In the present study, we tried to understand the effect and action mechanism of methyl isocyanate on E. coli membrane architecture. The lethal effect of MIC on E. coli membrane architecture using atomic force microscopy (AFM) enables us to explore direct microscopy imaging of cell damage. The effect and action mechanism of methyl isocyanate on E. coli is revealed via AFM imaging. To detect cell morphology, preliminary observation employing growth curve assay, colonogenic assay and cell hydrophobicity assay are also performed. Further, in silico study was performed using autodock to identify and provide a mechanistic study of the lethal effect of MIC and NSNM, which directly or indirectly affect E. coli membrane protein leading to its damage.

\section{Materials and Methods}

The strain of E. coli MTCC No.87 was procured from microbial type culture collection and gene bank (IMTECH, Chandigarh), N-succinimidyl N-methylcarbamate NSNM (CAS No. 18342-66-0) was purchased from Sigma Aldrich Laboratories, St. Louis, USA, and all other reagents used are of analytical grade.

\section{Growth curve assay}

E. coli was grown overnight using nutrient broth at $37^{\circ} \mathrm{C}$. After incubation $0.2 \mathrm{~mL}$ of $1 \times 108 \mathrm{CFU} / \mathrm{ml}$ suspension of $E$. coli was transferred to $20 \mathrm{~mL}$ of fresh media containing different concentration of NSNM from $0.25 \mathrm{mM}$ to $20 \mathrm{mM}$. Suspension without NSNM was used as control. Optical density was measured at different time intervals $(0,2,4,6,12$ and $24 \mathrm{~h})$ at $600 \mathrm{~nm}$. An experiment was repeated thrice.

\section{Clonogenic assay}

Clonogenic cell survival assay was used to determine the ability of a cell to proliferate and to form a large colony or a clone. E. coli culture was treated with different concentration of NSNM from $0.25 \mathrm{mM}$ to $20 \mathrm{mM}$ for $4 \mathrm{~h}$, followed by spreading on nutrient agar plates. Several growing E. coli colonies in nutrient agar plates was counted after $24 \mathrm{~h}$ of incubation at $37^{\circ} \mathrm{C}[18]$. An experiment was repeated thrice.

\section{Cell surface hydrophobicity (CSH) assay}

E. coli cell-surface hydrophobicity was determined as per the described method [19]. Briefly, after 24 h incubation, treated and control cultures of $E$. coli were harvested by centrifugation (5000x rpm for $20 \mathrm{~min}$ at $4{ }^{\circ} \mathrm{C}$ ) and washed thrice with normal saline, resuspended and absorbance was measured at $600 \mathrm{~nm}$ (OD1). $5 \mathrm{~mL}$ of E. coli suspension was mixed with $1 \mathrm{~mL}$ p-xylene and vortexed for 1min and then incubated for $30 \mathrm{~min}$ without disturbing to ensure that the two liquids had separated into layers. The absorbance of the aqueous layer was measured at $600 \mathrm{~nm}$ (OD2). Experiment was repeated thrice. E. coli culture surface hydrophobicity was expressed as percentage hydrophobicity index (\%HI) and calculated using the following formula.

$\% \mathrm{HI}=[1-(\mathrm{OD} 1 / \mathrm{OD} 2)] \times 100$

\section{Atomic force microscope}

Atomic force microscope (AFM) experiments were performed by using an NT-MDT NEXT Integrated Research Atomic Force Microscope, Russia. Two to three areas of each slide were scanned using the contact mode. The cantilevers tip with force constant of $10 \mathrm{~N} / \mathrm{m}$ and have a typical resonance frequency of $250 \mathrm{kHz}$ was used. A $2 \mathrm{~mL}$ of cell suspension was centrifuged at $4000 \mathrm{~g}$ for $5 \mathrm{~min}$, the cell pellet was resuspended in normal cold saline. Finally, $50 \mu \mathrm{L}$ portion of the cell suspension was placed on a freshly cleaved glass substrate and dried [20]. The parameters such as surface roughness include mean roughness $(\mathrm{Ra})$ and root mean square roughnesses $(\mathrm{Rq})$ were calculated.

\section{In-silico analysis}

E. coli membrane proteins selected for the present study are outer membrane protein OmpW, outer membrane protein OmpX, outer membrane protein OmpF porin, outer membrane protein OmpA, and periplasmic domain PAL (Protein Data Bank (PDB) ID: 2F1T, 1QJ8, 2ZFG, 2GE4 and 1OAP respectively) whose three-dimension structure were obtained for docking from protein data bank and used as a target; water molecules are removed from the PDB file. The possible binding active sites in proteins were identified with the help of the CASTp server [21].

\section{Preparation of ligand}

N-Succinimidyl-N-Methylcarbamate (NSNM) and Methyl isocyanate (MIC) (PubChem CID 4381935 and CID 12228) were used as ligands in the present study and were retrieved as a Standard Delay Format (SDF) from Pubchem Compound Database. Ligands are converted into PDB format using open babel software [22]. 
Singh et al. I Effects of carbamate pesticides intermediates on Escherichia coli membrane

\section{Molecular docking}

PyRx 0.8 a plugin of Autodock software were used for molecular docking simulations studies. The Lamarckian Genetic Algorithm (LGA) and grid-based energy evaluation method were used for the docking study. Water molecules were removed, and the protein structure containing only amino acid residues are considered for the study. Using an auto grid, grid points with 0.375 Á spacing were calculated around the docking area for all ligand atoms. The parameter used for docking calculation are mutation rate, crossover rate and population size; the best-docked conformations were obtained with a population size of 150 mutation rate of 0.02 and crossover rate of 0.8 . Results were evaluated based on root mean square deviation (RMSD) and orientation. Dock energy is the sum of the intermolecular and the internal energies and is represent as $\Delta \mathrm{G}$. Further, the best pose was selected, which possesses the lowest estimated binding free energy [23].

\section{Statistical analysis}

All the analytical experiments were carried out in triplicates $(n=3)$. Data were presented as mean \pm standard deviation (SD). Statistical analysis was performed by Graph Pad Prism 5.0 (San Diego, CA, USA).

\section{Results and Discussion}

In the current investigation, we found that N-Succinamidyl N-Methyl Carbamate (a synthetic analogue of methyl isocyanate) has an impact on cell health, and so we wanted to explore the way in which it is hazardous. MIC may enter cell membranes and then cross cell membranes to get to distant organs [5]. Study findings related to DNA damage, cell cycle arrest, and apoptosis were critical in helping us better understand the toxicological consequences of NSNM. Genotypic susceptibility to many infectious illnesses, as well as other environmental exposures, necessitates extensive discussion. The study's aim was to determine the reaction profiles of E. coli to NSNM, and then to investigate how different the response patterns are across other strains. In response to treatment with a synthetic counterpart of methyl isocyanate, it was found that the proliferation of E. coli was diminished. It illustrates that at a concentration of $2 \mathrm{mM}$, there is a substantial growth rebound after 24 hours; at a concentration of $5 \mathrm{mM}$, the growth of $E$. coli is totally blocked and there is no growth rebound (Figure 1). Additional NSNM effects, via modulating the growth curve of E. coli by either influx or extrusion, may influence a cell's ability to acquire new mutations. Toxicants entering the organism's cells and influencing their cellular activity is required for modulation to occur. The findings of the current investigation demonstrate that exposure to a final concentration of $2 \mathrm{mM}$ NSNM reduced the E. coli growth curve pattern by entrance into it.

We evaluated the growth-inhibitory effect of NSNM in a clonogenic cell survival test as well. During this experiment, various doses $(0.25 \mathrm{mM}$ to $20 \mathrm{mM})$ of NSNM were used to treat E. coli cultures for 4 hours, followed by spreading the bacteria over nutritional agar plates. Colonies were counted after 24 hours of incubation at $37^{\circ} \mathrm{C}$ on nutrient agar plates. In these experiments, it was discovered that treatment with NSNM reduced the number of viable E. coli cells in a dose-dependent manner (Figure 2).

The effect of oxidative stress on surface hydrophobicity was studied by quantitative surface hydrophobicity assay. The surface hydrophobicity of E. coli plays an important role in adherence to host cells. Surface hydrophobicity was significantly decreased when subjected to exposure with different concentration of NSNM. 5mM NSNM exhibits higher variation in cell surface hydrophobicity as compared to others (Figure 3). The above discussion supports the understanding that NSNM generates oxidative stress and plays a central role in altering the morphology, which directly affects the adherence capacity of E. coli. In addition, the surface properties of treated E. coli were found to be altered, which indicates its morphological changes. Cell surface hydrophobicity studies help us to identify morphological changes. The results indicate that the overall hydrophobicity of the cell surface was greatly influenced by the presence of NSNM. Kustos et al. 2003 showed observed similar alterations [26].

AFM was used to visualize the effect of NSNM on E. coli cell membrane surface. An AFM image of an untreated (control) E. coli shows no visible pores or ruptures (Figure 4A). Changes in membrane surface of E. coli treated with 0.25 $\mathrm{mM}, 0.5 \mathrm{mM}$ and $1 \mathrm{mM}$ were observed (Figure $4 \mathrm{~B}, \mathrm{C}$ and D). Further ultrastructure microscopy of treated cells was performed to justify our finding; exposure of the cells to $0.25 \mathrm{mM}$ NSNM induced minor perturbations on E. coli in comparison to control cells. Membrane blebbing and collapse at the apical end of the bacterial envelope were observed upon treatment with 1mM NSNM [27]. Topographical parameter like surface roughness includes mean roughness (Ra), and rootmean-square roughness $(\mathrm{Rq})$ was observed. The interaction of NSNM with cell membrane leads to an increase in surface roughness; which is the evidence of membrane damage (Table 1) [28].

The results obtained after docking showed strong binding affinities with MIC and its analogue NSNM (Table 2). Out of the five outer membranes protein selected, three proteins, namely 2ZFG, 2F1T and 2GE4, showed significant binding interactions with ligands (Figure 5). In outer membrane protein OmpF complex with NSNM, a strong hydrogen bonding interaction was observed with the ARG140 and SER142 amino acid residues as shown in (Figure 5A). Whereas outer membrane protein OmpF complex with MIC, a strong hydrogen bonding interaction was observed with the ARG100 and ARG132 amino acid residues as shown in (Figure 5F). In order to identify a protein involved during the membrane toxicity, 
we have performed molecular docking using Autodock 4.0. The results showed that outer membrane protein OmpF shows highest negative binding energy, i.e. $\Delta \mathrm{G}-4.11 \mathrm{kcal} / \mathrm{mol}$ and $\Delta \mathrm{G}-3.19 \mathrm{kcal} / \mathrm{mol}$ by NSNM and MIC respectively when compared to other proteins [7]. Thus, OmpF, which is involved in the passage of solutes such as sugars, ions, and amino acids which are crucial for entry into survival mode in stress condition, was found to be inhibited. Thus, the above study infers that NSNM and MIC cause cell death due to membrane protein damage of E. coli.

According to the findings, the toxicity of methyl isocyanate on E. coli was discovered. Additionally, E. coli was shown to have toxic effects that restrain growth in the presence of NSNM. The E. coli show decreasing vitality after they have been treated with NSNM. Methyl isocyanate is toxic to cells because it increases hydrophobicity on the bacterial cell surface, and the damage it causes is thus determined by calculating the effects of in vitro exposure to NSNM on cellular oxidative stress, which in turn produces cell harm. E. coli's surface has been harmed by exposure to NSNM, according to AFM investigation, and support the significant hazardous potentials of NSNM. The presence of increased surface roughness means that the membrane has been exposed to oxidative stress, allowing a cellular component to be released from the cell envelope. According to the binding contact capacities of NSNM and MIC with membrane proteins, the findings are supported.

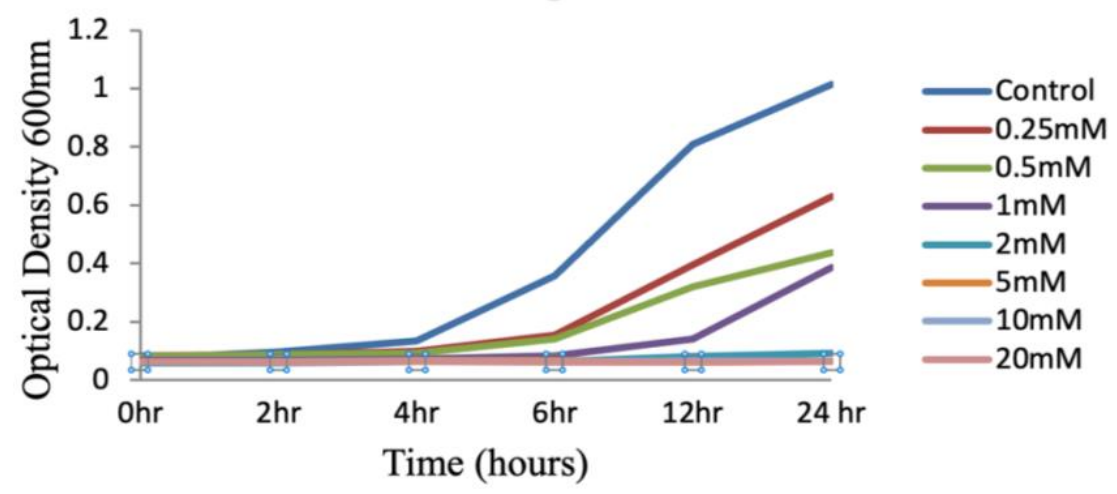

Figure 1. Growth curves assay: E. coli treated with $0.25 \mathrm{mM}$ to $20 \mathrm{mM}$ concentrations of NSNM along with control.

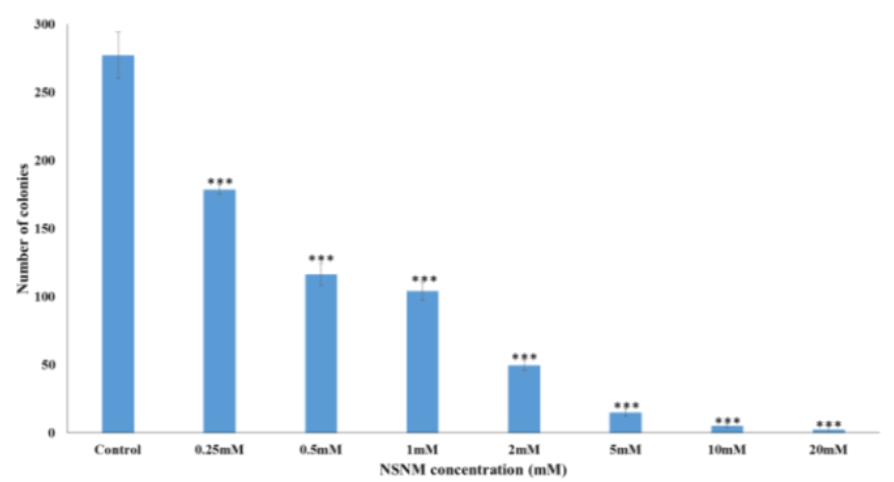

Figure 2. Clonogenic cell survival assay; number of colonies count on E. coli nutrient agar plate. Values are standard deviation of three independent plates $\left({ }^{*} \mathrm{P}<0.05,{ }^{* *} \mathrm{P}<0.01,{ }^{* * *} \mathrm{P}<0.001\right)$.

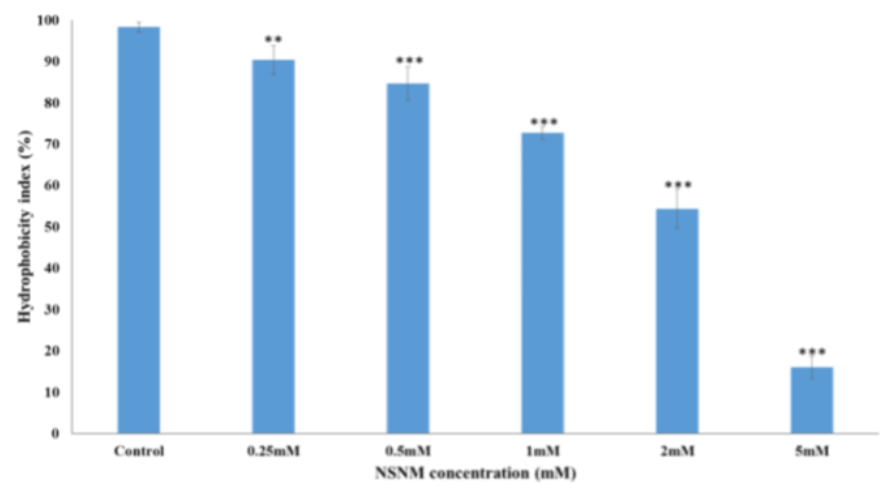

Figure 3. Cell Surface Hydrophobicity (CSH) Assay; percentages of hydrophobicity index of treated and E. coli culture

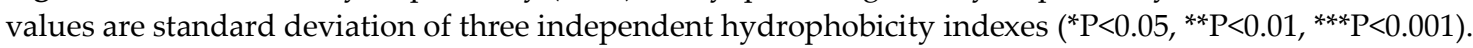



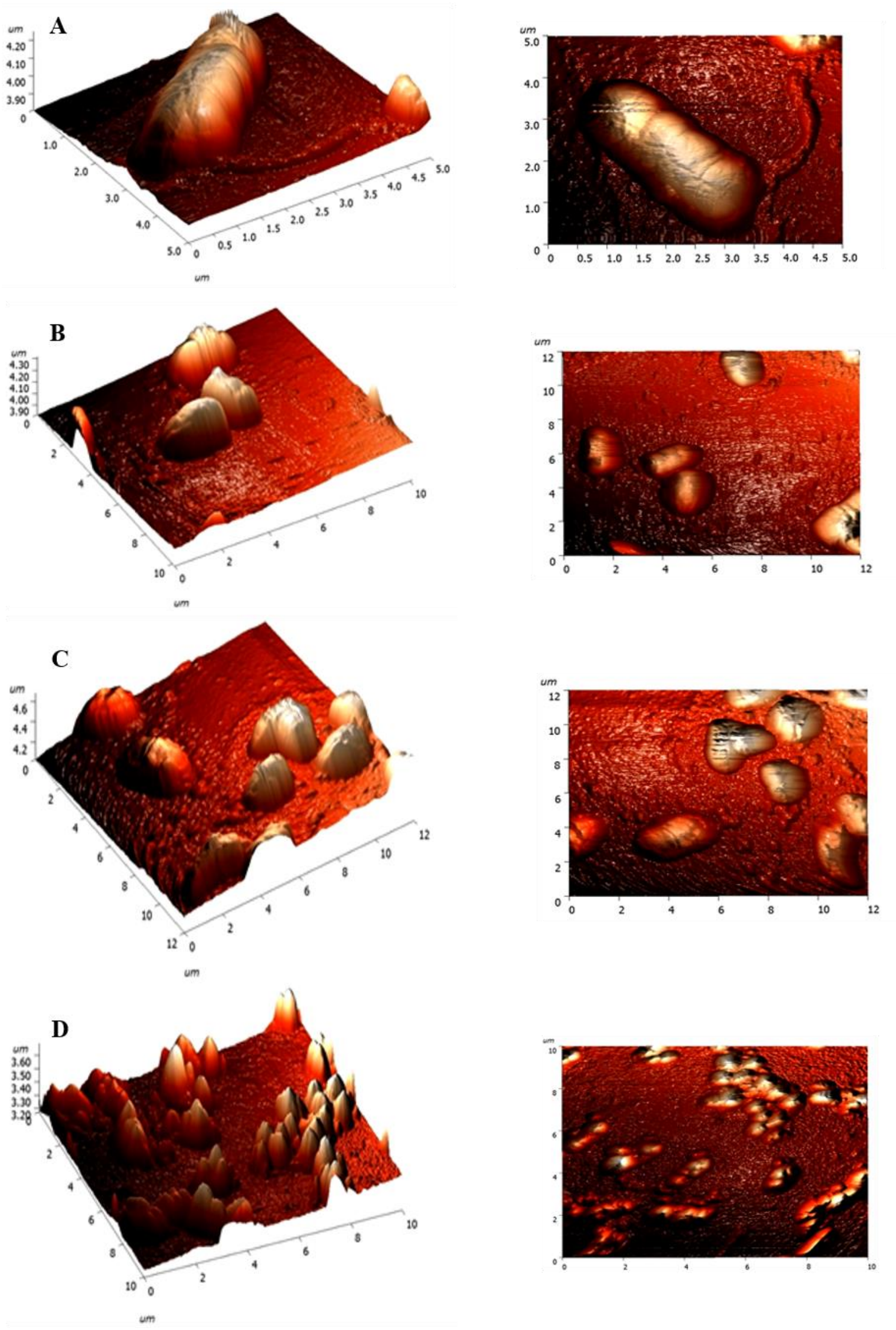

Figure 4. Atomic force microscopic images-AFM 3D images (left) and 2D images (right) of E. coli control culture: (A) and treated with NSNM concentration such as $0.25 \mathrm{mM}(\mathrm{B}) ; 0.50 \mathrm{mM}(\mathrm{C}) ; 1 \mathrm{mM}$ (D). 


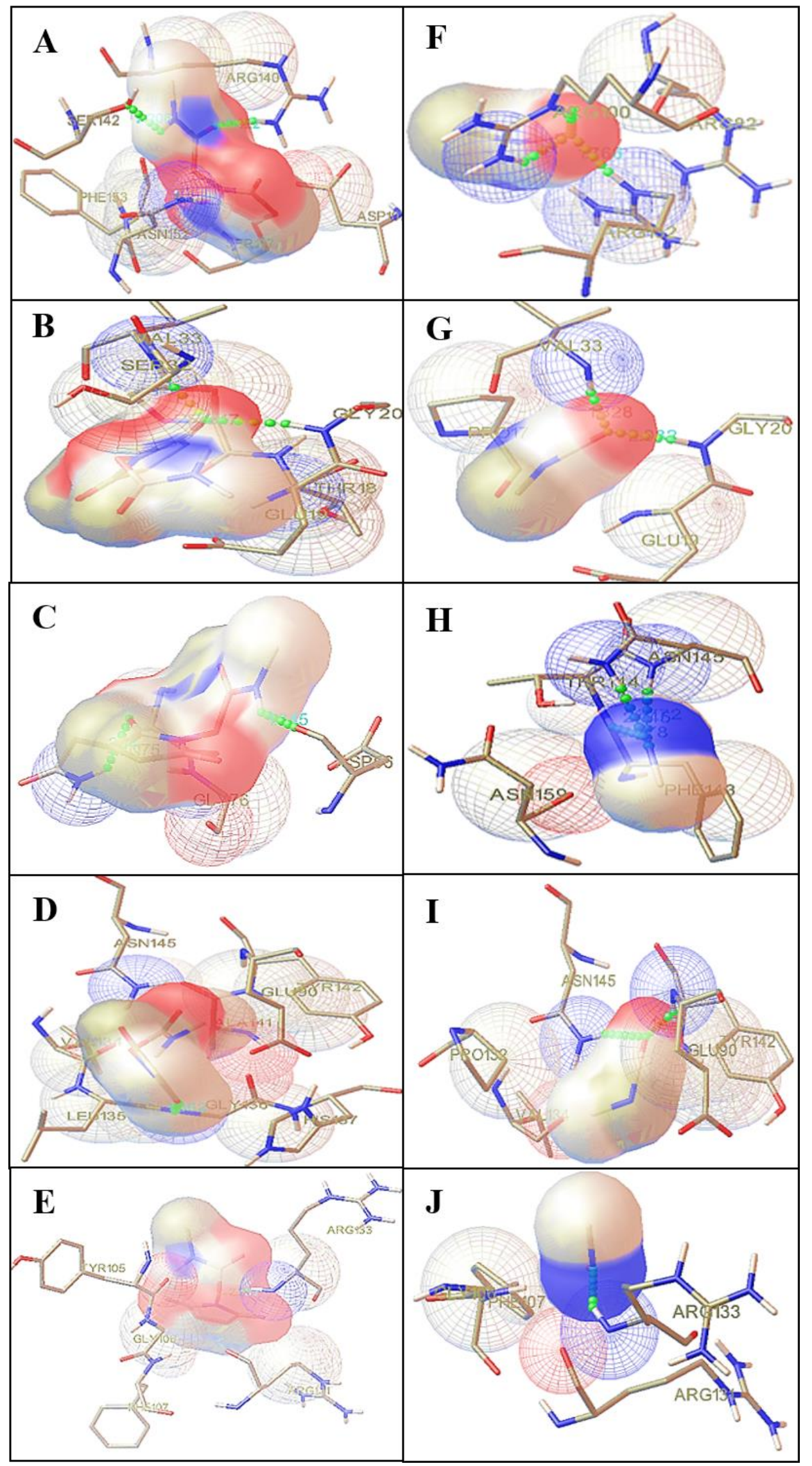

Figure 5. Protein ligand interaction: A-E indicates interaction between N-succinamidyl N-methyl carbamate (NSNM) with protein 2ZFG (A); 2F1T (B); 2GEM (C); 1OAP (D), 1QJ8 (E). F-J indicates interaction between methyl isocyanate (MIC) with 2ZFG (F); 2F1T (G); 2GEM (H); 1OAP (I); 1QJ8 (J). 
Table 1. Surface roughness analysis of E. coli culture.

\begin{tabular}{ccc}
\hline Sample & Rq (RMS profile deviation) & Ra (Arithmetic roughness) \\
\hline Control & 14 & 12 \\
$0.25 \mathrm{mM}$ & 26 & 21 \\
$0.5 \mathrm{mM}$ & 49 & 47 \\
$1 \mathrm{mM}$ & 95 & 85 \\
\hline
\end{tabular}

Table 2. Results of molecular docking.

\begin{tabular}{|c|c|c|c|c|c|c|c|c|}
\hline \multirow{2}{*}{$\begin{array}{c}\text { Ligand } \\
\text { Protein } \\
\text { Name \& ID }\end{array}$} & \multicolumn{4}{|c|}{ NSNM } & \multicolumn{4}{|c|}{ MIC } \\
\hline & BE (kcal/mol) & $\begin{array}{c}\mathrm{IC} \\
(\mathrm{mM})\end{array}$ & AAR & $\begin{array}{l}\text { BL } \\
(\AA)\end{array}$ & $\begin{array}{c}\text { BE } \\
\text { (kcal/mol) }\end{array}$ & $\begin{array}{c}\mathrm{IC} \\
(\mathrm{mM})\end{array}$ & AAR & $\begin{array}{l}\text { BL } \\
(\AA ̊)\end{array}$ \\
\hline $\begin{array}{l}\text { OmpF } \\
\text { 2ZFG }\end{array}$ & -4.11 & 0.969 & $\begin{array}{l}\text { ARG140 } \\
\text { SER142 }\end{array}$ & $\begin{array}{l}2.022 \\
2.432\end{array}$ & -3.19 & 4.59 & $\begin{array}{l}\text { ARG100 } \\
\text { ARG132 }\end{array}$ & $\begin{array}{l}1.766 \\
1.953\end{array}$ \\
\hline $\begin{array}{l}\text { OmpW } \\
\text { 2F1T }\end{array}$ & -3.9 & 1.38 & $\begin{array}{l}\text { GLY20 } \\
\text { VAL33 }\end{array}$ & $\begin{array}{l}3.06 \\
2.85\end{array}$ & -3.13 & 5.12 & $\begin{array}{l}\text { GLY20 } \\
\text { VAL33 }\end{array}$ & $\begin{array}{l}3.13 \\
3.24\end{array}$ \\
\hline $\begin{array}{c}\text { OmpA } \\
\text { 2GE4 }\end{array}$ & -3.72 & 1.88 & $\begin{array}{l}\text { GLY75 } \\
\text { ASP56 }\end{array}$ & $\begin{array}{l}2.245 \\
2.043\end{array}$ & -3.01 & 6.22 & $\begin{array}{l}\text { ASN145 } \\
\text { THR114 } \\
\text { PHE143 }\end{array}$ & $\begin{array}{l}2.045 \\
2.178 \\
1.176\end{array}$ \\
\hline $\begin{array}{c}\text { Pal } \\
1 \mathrm{OAP}\end{array}$ & -2.84 & 8.29 & $\begin{array}{l}\text { GLY142 } \\
\text { ALA135 } \\
\text { LEU136 }\end{array}$ & $\begin{array}{l}1.649 \\
1.662 \\
1.861\end{array}$ & -2.74 & 9.88 & $\begin{array}{l}\text { GLU90 } \\
\text { ASN145 }\end{array}$ & $\begin{array}{l}1.649 \\
1.856\end{array}$ \\
\hline $\begin{array}{c}\text { OmpX } \\
\text { 1QJ8 }\end{array}$ & -2.47 & 15.42 & ARG 133 & 2.239 & -1.86 & 43.11 & ARG133 & 2.143 \\
\hline
\end{tabular}

BE - Binding Energy, IC - Inhibition Constant, AAR - Amino Acid Residue, BL - Bond Length.

\section{Conclusions}

Studies on the NSNM and MIC proteins concluded that the outer membrane protein showed high binding affinities with NSNM and MIC. Additionally, researchers found that outer membrane protein (OmpF) is beneficial in survival mode under stress.

\section{Acknowledgement}

Authors are thankful to Prof. K.K.S. Gautam, Department of Physics, Maulana Azad National Institute of Technology, Bhopal for atomic force microscopy (AFM).

\section{Conflict of interest}

The authors declare that they have no conflict of interest.

\section{CRediT author statement}

PS: Conceptualization, Methodology, Writing- Original draft preparation; MKS: Investigation, Data curation, WritingOriginal draft preparation; AR and MY: Visualization, Investigation; RS: Supervision, Writing- Reviewing and Editing.

\section{ORCID}

Pushpendra Singh: 0000-0002-9619-0659

Manish Kumar Tripathi: 0000-0003-2546-9123

Rahul Shrivastava: 0000-0002-8544-5046 


\section{References}

[1] Akindoyo JO, Beg MDH, Ghazali S, Islam MR, Jeyaratnam N, Yuvaraj AR. Polyurethane types, synthesis and applications -a review. RSC Adv 2016;6(115):114453-114482. http://doi.org/10.1039/C6RA14525F

[2] Bengtström L, Salden M, Stec AA. The role of isocyanates in fire toxicity. Fire Sci Rev5 2016;4. https://doi.org/10.1186/s40038-016-0013-2

[3] Karol MH, Dean JH. Respiratory effects of inhaled isocyanates. CRC Crit Rev Toxicol 1986;16(4):349-379. https://doi.org/10.3109/10408448609037467

[4] Tripathi MK, Yasir M, Singh P, Shrivastava R. A comparative study to explore the effect of different compounds in immune proteins of human beings against tuberculosis: an in-silico approach. Curr Bioinform. 2020;15(2):155-164. https://doi.org/10.2174/1574893614666190226153553

[5] Varma DF, Guest I. The Bhopal accident and methyl isocyanate toxicity. J Toxicol Environ Health 1993;40(4):513-529. https://doi.org/10.1080/15287399309531816

[6] Shrivastava R. Bhopal gas disaster: Review on health effects of methyl isocyanate. Res J Environ Sci 2012;5(2):150. https://doi.org/10.3923/rjes.2011.150.156

[7] Tripathi MK, Yasir M, Singh P, Tayubi IA, Gupta R, Shrivastava R. Toxic effect of chemicals dumped in premises of UCIL, Bhopal leading to environmental pollution: An in silico approach. Asian Pacific J Trop Dis 2016;6(4):284-290. https://doi.org/10.1016/S2222-1808(15)61032-5

[8] Varma R, Varma DR. The Bhopal disaster of 1984. Bull Sci Technol Soc 2005;25(1):37-45. https://doi.org/10.1177/0270467604273822

[9] Mishra P, Samarth RM, Pathak N, Jain SK, Banerjee S, Maudar KK. Bhopal gas tragedy: Review of clinical and experimental findings after 25 years. Int J Occup Med Environ Health 2009;22(3):193-202. https://doi.org/10.2478/v10001$\underline{009-0028-1}$

[10] Mishra PK, Raghuram GV, Bunkar N, Bhargava A, Khare NK. Molecular bio-dosimetry for carcinogenic risk assessment in survivors of Bhopal gas tragedy. Int J Occup Med Environ Health 2015;28(6):921-939. http://doi.org/10.13075/ijomeh.1896.00313

[11] Tripathi MK, Yasir M, Gurjar VS, Bose P, Dubey A, Shrivastava R. Insights from the molecular docking of hydrolytic products of methyl isocyanate (MIC) to inhibition of human immune proteins. Interdiscip Sci Comput Life Sci 2015;7:287294. https://doi.org/10.1007/s12539-015-0012-3

[12] Mishra PK, Panwar H, Bhargava A, Gorantla VR, Jain SK, Banerjee S, et al. Isocyanates induces DNA damage, apoptosis, oxidative stress, and inflammation in cultured human lymphocytes. J Biochem Mol Toxicol 2008;22(6):429-440. https://doi.org/10.1002/jbt.20260

[13] Mishra PK, Gorantla VR, Akhtar N, Tamrakar P, Jain SK, Maudar KK. Analysis of cellular response to isocyanate using N-succinimidyl N-methylcarbamate exposure in cultured mammalian cells. Environ Mol Mutagen 2009;50(4):328-336. https://doi.org/10.1002/em.20469

[14] Samarth RM, Gandhi P, Maudar KK. A retrospective review of cytogenetic studies on methyl isocyanate with special reference to the Bhopal gas tragedy: Is the next generation also at risk? Int J Occup Med Environ Health 2013;26(3):324336. http://doi.org/10.2478/s13382-013-0110-6

[15] Mason JM, Zeiger E, Haworth S, Ivett J, Valencia R. Genotoxicity studies of methyl isocyanate in salmonella, drosophila, and cultured chinese hamster ovary cells. Environ 1987;9(1):19-28. https://doi.org/10.1002/em.2860090104

[16] Bhattacharya BK, Sharma SK, Jaiswal DK. Binding of $\left[1-{ }^{14} \mathrm{C}\right]$ methyl isocyanate to erythrocyte membrane proteins. J Appl Toxicol 1996;16(2):137-138. https://doi.org/10.1002/(SICI)1099-1263(199603)16:2<137::AID-IAT317>3.0.CO;2-E

[17] Nikaido H. Molecular basis of bacterial outer membrane permeability revisited. Microbiol Mol Biol Rev 2003;67(4):593656. https://doi.org/10.1128/MMBR.67.4.593-656.2003

[18] Franken NAP, Rodermond HM, Stap J, Haveman J, Bree C. Clonogenic assay of cells in vitro. Nat Protoc 2006;1:23152319. https://doi.org/10.1038/nprot.2006.339 
[19] Rosenberg E, Kaplan N, Pines O, Rosenberg M, Gutnick D. Capsular polysaccharides interfere with adherence of Acinetobacter calcoaceticus to hydrocarbon. FEMS Microbiol Lett 1983;17(1-3):157-160.https://doi.org/10.1111/j.15746968.1983.tb00392.x

[20] Meincken M, Holroyd DL, Rautenbach M. Atomic force microscopy study of the effect of antimicrobial peptides on the cell envelope of Escherichia coli. Antimicrob Agents Chemother 2005;49(10):4085-4092. https://doi.org/10.1128/AAC.49.10.4085-4092.2005

[21] Dundas J, Ouyang Z, Tseng J, Binkowski A, Turpaz Y, Liang J. CASTp: computed atlas of surface topography of proteins with structural and topographical mapping of functionally annotated residues. Nucleic Acids Res 2006;34(suppl_2):W116-W118. https://doi.org/10.1093/nar/gkl282

[22] O’Boyle NM, Banck M, James CA, Morley C, Vandermeersch T, Hutchison GR. Open Babel: An open chemical toolbox. J Cheminform 2011;3:33.https://doi.org/10.1186/1758-2946-3-33

[23] Shrivastava R, Yasir M, Tripathi M, Singh P. In silico interaction of methyl isocyanate with immune protein responsible for Mycobacterium tuberculosis infection using molecular docking. Toxicol Ind Health 2016;32(1):162-167. https://doi.org/10.1177/0748233713498447

[24] Mishra PK, Bhargava A, Pathak N, Desikan P, Maudar KK, Varshney S, et al. Molecular surveillance of hepatitis and tuberculosis infections in a cohort exposed to methyl isocyanate. Int J Occup Med Environ Health 2011;24:94-101. https://doi.org/10.2478/s13382-011-0006-2

[25] Martinez J, Oiry J, Imbach JL, Winternitz F. Activated N-nitrosocarbamates for regioselective synthesis of Nnitrosoureas. J Med Chem 1982;25(2):178-182. https://doi.org/10.1021/jm00344a017

[26] Kustos T, Kustos I, Kilár F, Rappai G, Kocsis B. Effect of antibiotics on cell surface hydrophobicity of bacteria causing orthopedic wound infections. Chemotherapy 2003;49:237-242. https://doi.org/10.1159/000072447

[27] Alves CS, Melo MN, Franquelim HG, Ferre R, Planas M, Feliu L, et al. Escherichia coli cell surface perturbation and disruption induced by antimicrobial peptides BP100 and pepR*. J Biol Chem 2010;285(36):27536-27544. https://doi.org/10.1074/jbc.M110.130955

[28] Li H, Chen Q, Zhao J, Urmila K. Enhancing the antimicrobial activity of natural extraction using the synthetic ultrasmall metal nanoparticles. Sci Rep 2015;5:11033. https://doi.org/10.1038/srep11033 